\title{
EXCHANGE RATE VARIABILITY AND THE RISKINESS OF U.S. MULTINATIONAL FIRMS: EVIDENCE FROM THE BREAKDOWN OF THE BRETTON WOODS SYSTEM
}

Eli Bartov

Gordon M. Bodnar

Aditya Kaul

Working Paper 5323

\section{NATIONAL BUREAU OF ECONOMIC RESEARCH 1050 Massachusetts Avenue \\ Cambridge, MA 02138 \\ October 1995}

We would like to thank Francisco Delgado, Roger Edelen, Richard Levich, Richard Marston, Tom Pugel, Jay Shanken, Cliff Smith and an anonymous referee for comments. The study also benefitted from comments of seminar participants at Columbia University, the International Monetary Fund, the International Finance Division of the Board of Governors of the Federal Reserve System, and NYU. This work has also been presented at the 1995 annual meeting of the American Finance Association. We acknowledge Barbara Jennings for research assistance. The second author would like to thank the John M. Olin Foundation for financial support. This paper is part of NBER's research programs in Asset Pricing, and International Finance and Macroeconomics. Any opinions expressed are those of the authors and not those of the National Bureau of Economic Research.

(c) 1995 by Eli Bartov, Gordon M. Bodnar, and Aditya Kaul. All rights reserved. Short sections of text, not to exceed two paragraphs, may be quoted without explicit permission provided that full credit, including (3) notice, is given to the source. 


\title{
EXCHANGE RATE VARIABILITY AND THE \\ RISKINESS OF U.S. MULTINATIONAL \\ FIRMS: EVIDENCE FROM THE BREAKDOWN
}

\begin{abstract}
This study assesses the impact of exchange rate variability on the riskiness of U.S. multinational firms by examining the relation between exchange rate variability and stock return volatility and by decomposing this relation into components of systematic and diversifiable risk. Focusing on two periods around the 1973 switch from fixed to floating exchange rates, we find a significant increase in the volatility of U.S. multinational monthly stock returns corresponding to the period of increased exchange rate variability. This increase in stock return volatility is also significant relative to the increase in stock return volatility for firms in three control samples. Using a single factor market model, we show this increase in total volatility led to a significant increase in market risk (beta) for the multinational firms relative to the control samples between the two periods. Collectively, these results suggest that the increase in exchange rate variability after 1973 was perceived by investors to be associated with an increase in the riskiness of cash flows of multinational firms that required compensation in terms of higher expected returns.
\end{abstract}

Eli Bartov

Accounting Department

Stern School of Business

New York University

40 West 4th Street

New York, NY 10003
Gordon M. Bodnar

Finance Department

Wharton School

University of Pennsylvania

2300 SH-DH

Philadelphia, PA 19104-6367

and NBER
Aditya Kaul

Simon School of Business

University of Rochester

Rochester, NY 14627 


\section{Exchange Rate Variability and the Riskiness of U.S. Multinational Firms: Evidence from the Breakdown of the Bretton Woods System}

\section{Introduction}

The purpose of this study is to increase our understanding of the relation between exchange rates and stock prices on a firm level basis. Our investigation focuses on two perspectives. The first perspective further examines the relation between the U.S. dollar exchange rate and U.S. multinational firms' stock returns. Theoretical models such as Shapiro (1974) and Levi (1990) identify potential impacts that exchange rate changes can have on a multinational firm's cash flows; however, recent empirical research, such as Jorion (1990), has documented only a weak link between contemporaneous exchange rate changes and stock returns of U.S. multinational firms. Rather than examining the impact of exchange rate changes on multinational stock returns, we consider the impact of increased exchange rate variability on the stock return volatility of U.S. multinational firms. This examination of a relation between variances provides an additional framework for determining the importance of exchange rate changes for multinational firm stock price determination. Moreover, as we discuss below, this framework provides certain advantages over the existing studies using first moments for understanding the nature of the relation between exchange rates and stock prices.

The second perspective considers the breakdown of the impact of increased exchange rate variability on the stock return volatility of multinational firm between systematic risk and diversifiable risk. The motivation for this investigation follows from previous research that suggests a (small) positive link between the dollar risk premia on foreign currency deposits and the risk premia in the U.S. equity market during floating exchange rates (see, e.g., Chiang (1991), McCurdy and Morgan (1991), Giovannini and Jorion (1987), and Robichek and Eaker (1978)). Since multinational firms have substantial revenues and net assets denominated in foreign currency, we consider the possibility that 
exchange rate variability contributes to their systematic risk by increasing their market beta compared with nonmultinational (domestic) firms.

This breakdown between systematic and diversifiable risk has important implications for the impact of exchange rate variability on the expected rate of return of multinational firms. If the additional risk imparted to exposed firms from increased exchange rate variability is diversifiable, it is not directly relevant for pricing the firms because it can be diversified away by investors while constructing portfolios. Conversely, if some portion of this risk is systematic, it will affect the required rate of return. More specifically, in the presence of increased exchange rate variability, the cost of equity capital for multinational firms will increase relative to that of nonmultinational (domestic) firms.

In light of the difficulties of the previous empirical research, mentioned above, we attempt to increase the likelihood of detecting an empirical link between exchange rate variability, stock return volatility, and systematic risk, by focusing on the period around the breakdown of the Bretton Woods System with its associated movement from fixed exchange rates to flexible exchange rates and corresponding sharp increase in exchange rate variability. The choice of this time period also greatly reduces the likelihood of significant (unobservable) financial hedging of exchange rate exposure by multinational firms that could reduce the observed impact of exchange rate variability on stock returns.

Although exchange rates can affect the performance of (nearly) all firms in the economy, we focus our tests on U.S. non-oil multinational firms because they are more directly influenced by exchange rate fluctuations than most domestically oriented firms. This focus also enables us to create a control sample of "domestically oriented" firms in the same line of business to test for impacts of the exchange rate variability while controlling for the impact of other confounding influences. We also create an oil price sensitive sample to control for the possible impact of oil price exposure and create a size-matched sample of nonmultinational firms to control for possible confounding factors related to firm size (market capitalization). 
We find that the increase in exchange rate variability around the change in exchange rate regime is associated with a statistically significant increase in stock return volatility for U.S. multinational firms compared with the control firms. In addition, using a market model we show that some portion of the increased stock return volatility of the multinational firms is systematic in nature as the market risk (beta) of these firms rises in the period of increased exchange rate variability. Further, we demonstrate that this change in market risk is a change in asset risk, not financial risk. We interpret this evidence as suggesting that increased exchange rate variability leads to greater stock price variability of multinational firms and that investors recognize that the foreign currency activities of these firms entail additional nondiversifiable risk. As a result they increase the required rate of return, and thus cost of capital, for U.S. multinational firms.

The next section develops the research questions in detail and Section 3 discusses our research design and sample selection procedures. Section 4 presents the tests and results along with some sensitivity analysis. Section 5 summarizes our findings and provides some interpretation.

\section{Research Questions}

\subsection{Relation Between Exchange Rate Variability and Total Stock Return Variability}

Previous research has delineated the various ways in which exchange rate changes may affect the market value, and thus, the stock return of firms. These models suggest that exchange rate changes result in changes in expected real cash flows that change the current value of the firm. ${ }^{1}$ Empirical examination of this relation using stock returns and exchange rate changes have provided only weak evidence that exchange rate changes are significantly related to either firm or portfolio stock returns. These results

\footnotetext{
'It is interesting to note that these models (e.g., Shapiro (1974) and Levi (1990)) do not consider any impact of exchange rate fluctuations on the cost of capital for these firms.
} 
seem surprising given common perception of the importance of exchange rates for firm value and the selection of sample firms with substantial foreign activities in several of these studies. ${ }^{2}$

The limited success of these empirical studies on exchange rate exposure may be due to several problems. First, firms in the samples can be involved in many activities with different exposures to exchange rates that change over time, causing the firm's exposure to fluctuate, or even switch signs. Estimating exposures for portfolios of firms with offsetting exposures or for firms with fluctuating exposures will result in insignificant exposure coefficients even if exchange rates matter significantly for firm performance. Second, characterizing the exposures of firms on a timely basis may be difficult for investors due to complexities associated with their determination. Without extensive knowledge of international pricing policies, strategic responses to exchange rate changes, foreign currency positions, or experience in estimating firm operations, investors may wait for the firm to release information about its actual performance before they adjust firm value in response to past exchange rate changes resulting in a delayed rather than contemporaneous relation (see, e.g., Bartov and Bodnar (1994)). Thus tests requiring contemporaneous relations may fail to find significant exposures even when they exist economically. Finally, it is possible that firms that would appear to have exposures to exchange rate changes have eliminated them by taking offsetting positions in off-balance sheet financial instruments (derivatives). As disclosures of such activity have not been required until very recently, it is possible that the weak results are simply because the firms have effectively managed their exposures.

Examining the relation between exchange rate variability and stock return volatility can eliminate some problems confounding research on the relation between stock returns and exchange rate

\footnotetext{
${ }^{2}$ Jorion (1990) uses U.S. multinational firms from 1971-87, Amihud (1993) uses large U.S. exporters, most of which are also multinationals from 1980-88, Bodnar and Gentry examine firms on the CRSP tape segmented into 2 digit SIC code industry portfolios and Bartov and Bodnar (1994) examine firms from 1978-89 that report large exchange rate adjustment on their financial statements. The failure to identify significant exposures does not appear to be due to hedging activities as estimation of significant exchange rate exposures is difficult even in cases where data indicated the existence of sizeable foreign currency exposure net of hedging (see, e.g., Bartov and Bodnar (1994)).
} 
changes. First, by focusing on volatility, the sign of the exposure or its stability through time is much less important. Also, since variances are measured over a multi-period window, the examination of a relation between variances reduces the necessity that the impact of the exchange rate on stock prices be contemporaneous. These points suggest that tests examining variability are likely to offer several advantages over previous tests (mentioned above) in identifying a significant relation between exchange rates and firm value. However, if the low significance of the results is because firms are financially hedging their exposures, then these tests on second moments will offer no advantage. ${ }^{3}$

The discussion above implies that firms with exchange rate exposure (of any sign) should experience changes in firm value when exchange rates move. While exchange rate exposures can arise through competition with foreign firms, it arises most directly from doing business (having significant assets and revenues streams) in foreign currencies. Since multinational firms both compete directly against foreign firms and have significant foreign operations, this suggests that (in the absence of hedging) they are likely to be directly impacted by exchange rate changes. This leads us to our first research question that considers whether the stock return volatility of U.S. multinational firms' is increasing in the variability of U.S. dollar exchange rates. ${ }^{4}$

\footnotetext{
3 An assumption of imperfect (or perhaps even no) hedging seems reasonable, particularly for the early years of floating exchange rates, as there were only limited opportunities for the financial hedging of exchange risk, and firms in general had very little expertise in hedging what was essentially a new phenomenon. Evidence to support this assumption is presented in Smith, et al. (1990).

${ }^{4}$ Note that we are not attempting to argue that an increase in exchange rate variability is independent of an increase in the variability of underlying fundamental variables -- variables that may also result in increased stock return volatility for all firms. Instead, we hypothesize that the existence of assets and cash flows denominated in foreign currencies presents an additional avenue by which macroeconomic volatility, evidenced through increased exchange rate variability, can contribute to the volatility of U.S. multinational firms' returns.
} 


\subsection{The Relation Between Exchange Rate Variability and Systematic Risk}

In traditional asset pricing theory, the risk of an asset can be broken down into two parts: its systematic risk, which is proportional to the return on the equilibrium portfolio of assets, and its diversifiable risk, which is uncorrelated with the return on the equilibrium portfolio. In a welldiversified portfolio all idiosyncratic risks of individual assets are diversified away and only systematic risk remains. Standard asset pricing theory argues that in efficient markets only systematic risk receives compensation through higher required rates of return. Thus, an increase in a firm's systematic risk leads to an increase in the required rate of return and an increase in the cost of capital. Conversely, increases in diversifiable risk do not affect the expected rate of return or cost of capital. Thus, the distinction of whether the increase in total risk resulting from increased exchange rate variability is (partially) additional systematic risk or purely additional diversifiable risk has important implications for the firm.

One manner in which exchange rate variability could affect the systematic risk of firms is because exchange rate risk is priced as separate risk factor in a multifactor model (see, e.g., Solnik (1974) and Adler and Dumas (1983)). This possibility of a direct link between exchange rates and systematic risk is examined by Jorion (1991) in the context of a multifactor pricing model on U.S. industry portfolios. He tests this possibility by adding the change in a trade-weighted exchange rate as an additional factor to both the market model and the six-factor model of Chen Roll and Ross (1983) and applying the estimation technique proposed by Gibbons (1982). The results provide no evidence that this exchange rate variable is priced as an independent economic risk factor in the U.S. equity market over the period 1971 - 1987 or several subperiods thereof. He concludes that exchange rate risk does not unconditionally affect the expected returns of U.S. firms. ${ }^{5}$

\footnotetext{
5 The tests of such factor models for currency risk are plagued by the difficulties of estimating contemporaneous firm or portfolio level exchange rate exposures, discussed earlier.
} 
In contrast to this approach, we conjecture that exchange rate variability contributes to the systematic risk of multinational firms indirectly by increasing the sensitivity of the firm's return to the return of the equity market portfolio. Our motivation for considering this effect of exchange rate variability on a firm's systematic risk derives from the findings of prior research that indicates that the dollar risk premia on money market investments in the major foreign currencies move together with the dollar risk premium on the U.S. equity market during the floating rate period (see, e.g., Chiang (1991), McCurdy and Morgan (1991), Giovannini and Jorion (1987), and Robichek and Eaker (1978)). ${ }^{6}$ This research demonstrates that over the floating exchange rate period, U.S. investors' investments in major foreign currency deposits entailed risk that was not completely diversifiable as evidenced by (small) significantly positive correlations between realized excess returns on the currency positions and the excess return on a U.S. equity market index. ${ }^{7}$ Although this prior literature on foreign currency risk premia has identified this relation with an equity risk premium, we know of no study that investigates the impact of this feature of currency risk on the market risk of different classes of firms in the economy.

Given this evidence that deposits in foreign currencies under floating exchange rates possess a component of risk that is systematic from the point of view of U.S. investors, we would expect that firms with real activities in foreign currencies should experience an increase in overall market risk. Because they possess significant assets and revenues denominated in foreign currencies, this impact should be most identifiable for U.S. multinational firms. Conversely, U.S. firms with no foreign currency positions in their financial structure would not experience any increase in market risk due to the increased variability of exchange rates in the floating rate period. Thus our second research question considers

\footnotetext{
${ }^{6}$ Korajczyk and Viallet (1992) also demonstrate a small relation between the risk premia on foreign currencies and the equity premia for foreign markets.

${ }^{7}$ There are no studies we are aware of that consider whether any risk premia in foreign currency deposits during fixed exchange rates was also correlated with the U.S. equity market risk premium. We assume that no such correlation existed under fixed exchange rates. To the extent that this assumption is wrong it works against our finding any change in market risk for the multinationals between fixed and floating exchange rate periods.
} 
whether increases in exchange rate variability lead to increases in systematic risk, evidenced by market risk, for U.S. multinational firms.

\section{Research Design and Sample Selection}

\subsection{Research Design}

Our tests cover two five-year periods, five years of fixed rates prior to the breakdown of the Bretton Woods system, 1966 - 1970 during which time countries acted to maintain exchange rates within a narrow plus or minus 1 percent band around a central parity and the first five-years following the arrival of fluctuating exchange rates, $1973-1977 .^{8}$ These periods saw not only a fundamental change in the operation of the currency markets, but also a massive increase in the volatility of the foreign currency value of the U.S. dollar. ${ }^{9}$ This focus on across periods that experience a sharp change in variability should help to identify any relation between exchange rate variability and the stock return variability, if it exists.

The focus of our research questions on multinational firms allows us to create a matched control sample of firms in the same industries as each of the multinational firms but with no evidence of international activities in their financial statements. ${ }^{10}$ This test and control sample framework, which is a common feature in the literature, allows a direct comparison among firms that differ with respect to their international involvement but are similar in other respects, and, more important, are subject to the same

\footnotetext{
${ }^{8}$ We omit the years 1971 and 1972 as these were "transitional" years in which some exchange rates floated and then were fixed again as a result of the Smithsonian Agreement only to float permanently in March 1973, at which time all major currencies were determined by market forces. Our inclusion of the first months of 1973, while not actually part of the true floating rate period, works against our finding any difference between fixed and floating rate periods. Shifting our time period forward three months has no material impact of the results.

${ }^{9}$ Using a trade-weighted index of the U.S. dollar, the monthly variance of the foreign currency value of the dollar rose from 0.0009 to 0.0289 . An F-statistic for this change is 32.21 which is significant at the 1 percent level.

${ }^{10}$ While these domestic firms report no evidence of international activity in their financial statements, they may still be involved in some exporting or importing activity or may compete against foreign firms. This problem, if severe, works against our finding differences between the test and control samples.
} 
set of other confounding macroeconomic shocks. ${ }^{11}$ We extend this control group notion in two other directions. First, to control for possible influences of the OPEC oil shock of October 1973, we exclude firms with a high sensitivity to oil prices from our multinational sample and create a control sample of oil-price sensitive firms (defined as primary two-digit SIC codes $13,29,37,40-45$, and 49). ${ }^{12}$ Finally, as the multinational firms are much larger than the industry-matched control firms, we create a third control sample of the largest non multinational firms not in any of the other samples to control for possible differences in results due to firm size.

\subsection{Sample Selection}

The selection procedure for our test sample of multinational firms consists of several steps. An initial universe of potential firms is drawn from the Compustat Expanded Annual Industrial and Full Coverage File after imposing a firm-level data availability requirement that encompasses our sample period 1965 - 1978 as well as requiring continuous return data on the CRSP NYSE/AMEX Monthly Returns and Master File. These firms are then checked for the existence of foreign operations according to the 1965 version of the Directory of American Firms Operating in Foreign Countries. One hundred twenty-nine firms are identified as multinationals by having real operations in either Europe or Japan. ${ }^{13}$

\footnotetext{
"While the increase in exchange rate variability also potentially resulted in an increase in volatility for purely domestic firms through influences on interest rates and price levels for instance, we expect that if exchange rate variability has a direct influence on stock price volatility there should be a larger increase in volatility for our test sample of multinational firms than for our control samples.

${ }^{12}$ These industries are oil and gas extraction, petroleum refining, transport equipment, railroad transport, motor freight transport and warehousing, water transport, air transport and public utilities.

${ }^{13}$ Two points to note: 1) the Directory of American Firms Operating in Foreign Countries does not provide any quantitative data on the extent of the foreign operations; 2) firms with foreign operations in developing countries were excluded as currencies of these countries did not fluctuate freely and firms with operations exclusively in Canada were excluded as the Canadian dollar began floating against the U.S. dollar in 1970 and traditionally has not fluctuated substantially against the U.S. dollar.
} 
Finally, twenty of these firms are dropped because of sensitivity to oil prices. Thus, our test sample consists of 109 U.S. firms with foreign operations as of 1965.

To identify firms for the industry control sample, all non test-sample firms with no reported foreign operations at the beginning of the sample period are sorted by size within two-digit SIC code groups. Then, firms that report no evidence of international operations toward the end of the sample period, evidenced by no foreign currency adjustment reported in their income statements for 1976 and 1977 , are assigned into the industry control sample in the same numbers as their industry group appears in the test sample. When sufficient firms exist for a given industry group, the one closest in size to the test sample firm is chosen into the control sample. In cases where not enough firms with no evidence of foreign operations are available for a given industry to match the frequency in the test sample, we choose the firms in that industry with the smallest reported foreign currency adjustment. ${ }^{14}$

Oil sensitive firms are defined as those with primary two-digit SIC codes corresponding to oil drilling or refining operations, transportation industries, transport equipment industries, and utilities. Out of the firms in these industries with data over the entire sample period, we choose the 109 firms most closely matching the size of the test sample firms, without concern for the existence of international activities. ${ }^{15}$ Finally, the size control sample contains the 109 largest firms with relevant data over the sample period that are not chosen in the other two control samples. These firms must not be reported as

\footnotetext{
${ }^{14}$ Foreign currency adjustments were only required to be reported in financial statements following the adoption of Statement of Financial Accounting Standard No. 8 in December 1975. 92 of the 109 firms in our industry control sample reported no foreign currency adjustment. For the seventeen firms with foreign currency adjustments that were necessary inclusions in the control sample for industry matching purposes, the mean ratio of reported foreign currency adjustment to net income was relatively small (one percent). To the extent that firms with multinational operations did not report currency adjustments due to materiality, our industry control sample will contain some exchange rate exposure and our tests will be biased towards showing no difference between test and control samples.

${ }^{15}$ While many of the firms in the oil-sample may be U.S. multinational firms, oil in the world markets is priced in dollars and therefore does not directly produce an exchange rate exposure. While firms in the oil sample may have exchange rate exposures, we assume that this exposure is small relative to the importance of oil price fluctuations for these firms. However, to the extent that this assumption is not correct, the difference in predictions about relative stock price behavior between this sample and the test sample of multinational firms will be reduced.
} 
having foreign operations prior to the sample period and show no evidence of foreign operations in their financial statements for 1976 and 1977.

Table 1 displays a comparison of the first, second, and third quartiles of descriptive statistics for our multinational, industry control, oil control, and size control samples (the comparison is for fiscal year 1972, arbitrarily chosen). The difference in the size between the multinational sample and the industry control sample is quite noticeable. This is to be expected as firms with international activities are typically larger. ${ }^{16}$ However, debt-to-equity ratios are roughly similar between the multinational and industry control samples. The oil sample is also similar to the test sample with respect to market value, but larger in terms of total assets and smaller in terms of total sales. Oil-price sensitive firms also show higher debt-equity and $\mathrm{E} / \mathrm{P}$ ratios than the test sample. The size control sample appears to be a good match to the test sample in terms of market values and book value of assets; however, it differs substantially from the test sample with respect to debt-to-equity ratios.

\section{Tests and Results}

\subsection{Total Stock Return Variability}

To examine our first research question, we calculate the variance of the monthly returns for the firms in our samples over the two sixty-month windows. The first window, from January 1966 to December 1970 spans five years of fixed exchanges rates prior to the breakdown of the Bretton Woods Agreement (fixed exchange rate regime). The second window, from January 1973 to December 1977, consists of the first five years of the floating exchange rate period (floating exchange rate regime).

Summary statistics for the cross-sectional distribution of total stock return variability for the firms in each of the four samples for these two subperiods are displayed in Panel A of Table 2.

\footnotetext{
${ }^{16}$ This is a common feature of tests involving groups of multinational firms and groups of purely domestic firms in similar lines of business (see, e.g., Fatemi (1984)).
} 
Consistent with previous studies using U.S. data, comparison of the multinational sample with the industry control sample reveals that multinational firms display lower return volatility than similar purely domestic firms (see, e.g., Fatemi (1984)). All four samples show increased stock return volatility corresponding to the increased exchange rate variability. While we predicted this result for the multinational firms, it is not surprising that the control samples also display an increase in return volatility. The increase in exchange rate variability was accompanied by increased macroeconomic uncertainty, stemming from the oil price shock and the onset of increasing inflation, that can result in increased stock return volatility of all firms, as is apparent from the results in Panel A.

To evaluate the significance of the change in stock return variance for each sample across the two periods, we use the following chi-squared statistic:

$$
\chi^{2}(2 N)=-2 \sum_{i=1}^{N} \ln p_{i}
$$

where: $p_{i}$ is the $p$-value for the F-statistic of the test of the change in variances for firm $i$

$\mathrm{N}$ is the number of firms in each sample.

Since under the null hypothesis of no change in stock return variability across the exchange rate regimes the sample distribution of F-statistics is random, this statistic is asymptotically distributed chi-squared with $2 \mathrm{~N}$ degrees of freedom. ${ }^{17}$ This statistic, reported across from the means in Panel A of Table 2, suggests that we can reject the null hypothesis in favor of the alternative hypothesis that the volatility of monthly stock returns of all four samples is higher in the floating exchange rate period than in the fixed rate period.

Panel A of Table 2 also displays the results of a non-parametric Wilcoxon signed-rank test for the median variance shift to eliminate the effect of possible outliers. As with the chi-squared test, the

\footnotetext{
${ }^{17}$ See Theil (1971, pp. 98-100, 396-97). This test statistic assumes that the observations are independent of one another.
} 
Wilcoxon signed-rank tests allow us to reject the null hypothesis of no change in the distribution of sample variances across exchange rate regimes at the 1 percent level for all samples.

These results indicate an increase in stock return volatility for all firms, not just multinationals, corresponding to the period of increased exchange rate variability. This may be either because exchange rate variability affects the stock return volatility of all firms or, more likely, that the large increase in exchange rate variability is correlated with other forms of increased macroeconomic uncertainty. The implication of our first research question and the assumption that multinationals are more sensitive to exchange rate fluctuations is that the stock price volatility of multinationals firms should increase more than that of the control firms. We test this hypothesis by comparing the cross sectional distribution of the relative stock return variances between the two periods across the four samples. Specifically, for each firm we calculate the ratio of the monthly stock return variance in the floating rate period to the monthly stock return variance in the fixed rate period. Since these firms were all subjected to the same macroeconomic uncertainty, under the null hypothesis that the increase in exchange rate variability did not play an incremental role in the stock return variability of U.S. multinational firms, the cross sectional distributions of these variance ratios should be similar across all four samples. The cross sectional distribution of these ratios is shown in Panel B of Table 2. For all the distribution statistics (mean, median, quartiles), the test sample has higher variance ratios than either of the three control samples.

Rather than impose some distributional assumptions on the relative variances, we test whether the distributions of the variance ratios for the industry control, oil control, and size control sample firms are statistically different from the distribution of the test sample firms using a Wilcoxon rank-sum test. These test statistics are reported in Panel B of Table 2. The distribution of the variance ratios for the test sample of multinational firms is significantly different from that of the industry control, the oil price control and size control sample at the 5 percent level. These results suggest that the relative increase in stock return variance between the fixed exchange rate period and the floating exchange rate period is 
significantly larger for U.S. multinational firms than for similar (mostly) domestic firms as well as oilprice sensitive firms. ${ }^{18}$

To add support to this result, we also consider the stock return volatility of equally-weighted portfolios of the firms in each sample. ${ }^{19}$ We calculate the variance of the monthly returns for the portfolios over the two periods. The results, shown in Panel C of Table 2 are consistent with the cross sectional results of Panel B. The test sample portfolio has a variance of 0.0026 in the fixed exchange rate period that rises to 0.0041 in the floating exchange rate period. An F-test indicates that this increase in variance is significant at the 5 percent level. For the control sample portfolios, the return variance increases between the two periods; however, in none of these cases is it significant at standard levels.

Overall these results suggest that the stock return variability of multinational firms is positively related to exchange rate variability. ${ }^{20}$ These results are important because they are consistent with the theoretical exchange rate exposure literature that suggests that exchange rate movements are associated with the movements in stock returns of firms with international activities and add support to the (weak) empirical evidence on the impact of exchange rate changes on firm value.

\footnotetext{
${ }^{18}$ The increases in variance measured by differences (rather than ratios) is also larger for the test sample than the control samples. The increase in the mean variance between periods is 0.0030 for the test sample, and only $0.0024,0.0014$, and 0.0023 for the industry oil, and size control samples, respectively. The same ordering also holds for the medians and quartiles. Tests (not reported) indicate, however, that the increases in variance for the test sample is only significantly larger when compared to the oil control sample.

${ }^{19}$ Note that portfolio test on the multinationals is not likely to be as powerful a test as the firm-level tests because the portfolio is created without worry as to whether the impact of exchange rate change are positive or negative. To the extent that some firms act as natural hedges of others to given exchange rate changes, the change in portfolio volatility will understate the "true" change in stock price volatility in response to increased exchange rate variability. This impact is less severe for the other samples as it is less likely that exchange rates have a direct impact on their stock price behavior.

${ }^{20}$ Alternatively, these results may be interpreted as implying that increased exchange rate variability contributes relatively more to increased stock return volatility of U.S. multinational firms than other less multinational firms.
} 


\subsection{The Impact of Exchange Rate Variability on Market Risk}

This section examines the question of whether the increased exchange rate variability leads to increased market risk for our test sample of multinational firms (our second research question). To consider this possibility, we employ a single factor market model, where the market is the U.S. domestic market portfolio. ${ }^{21}$ We model over both the fixed and floating exchange rate periods and look for a change in market risk by testing for a structural shift in the market beta.

We estimate, firm-by-firm, the following regression over the period 1966-1977 omitting the years 1971 and 1972:

$$
R_{i, t}=a_{0}+\beta_{1, i} \cdot R_{m, t}+\beta_{2, i} \cdot R_{m, i} \cdot D U M_{1}+\epsilon_{i, t}
$$

where: $R_{i, t}=$ the monthly raw return to firm $i$ in month $t$;

$R_{m, t}=$ the monthly return to the CRSP value-weighted U.S. market index in month $t$; DUM $_{t}=$ dummy variable set to $I$ for $1973-1977$ and zero otherwise; $\epsilon_{i, t}=$ residual of firm $i$ for month $t$.

The coefficient $\beta_{1, \mathrm{i}}$ is the index of market risk during the first period $(1966-1970)$ and $\beta_{2 . \mathrm{i}}$ is the shift in the index of market risk during the floating exchange rate period $(1973-1977)$ for firm $i$. If increased exchange rate variability is associated with an increase in the market risk of multinational firms, the $\beta_{2, i} s$ will be significantly positive for our test sample firms. Since changes in market risk may be correlated with the lines of business, or some other common feature of firms, we also carry out the same test for the control samples to try to isolate the impact of any shift in market risk to exchange rate induced stock price volatility.

\footnotetext{
${ }^{21}$ In the analysis that follows we use the return to the valued-weighted market index of the Center for Research on Security Prices (CRSP). This is a portfolio of firms listed on the NYSE and AMEX markets. It may be argued that the appropriate market for this analysis is a world market portfolio. We believe that there are several reasons that the U.S. market is appropriate for pricing these U.S. firms over this period. First, as noted in Solnik (1991), the U.S. market accounted for over 61 percent of world market capitalization in 1972; second, there were substantial restrictions on foreign stock ownership across most countries (except through domestic multinational firms) at the time; third, as demonstrated by Jacquillat and Solnik (1978), U.S. multinational firms had betas very close to zero with respect to other national market indices. Although we were not able to find nor able to construct a world-market index for the full time period under study, we do examine the sensitivity of the results to the use of the U.S. domestic market portfolio by adding exchange rate and interest rate variables in Section 4.4 below.
} 
To test the significance of the change in market risk, we compute t-statistics for the $\beta_{2}$ s for each firm in the samples. Two parametric tests are carried out. First we consider the significance of the mean of the cross-sectional distribution of $\beta_{2}$ s for each sample using the sample standard error of the mean. Second, we compute a Z-statistic from the distribution of the t-statistics for each sample:

$$
\mathrm{Z}=\left(\frac{1}{\sqrt{N}}\right) \sum_{i=1}^{N} \frac{t_{i}}{\sqrt{k_{i} /\left(k_{i}-2\right)}}
$$

where: $\quad t_{i}=t$-statistic for the estimate of $\beta_{2}$ for firm i;

$\mathrm{k}_{\mathrm{i}}=$ degrees of freedom for firm $\mathrm{i}$;

$\mathrm{N}=$ the number of firms in the sample;

Since the $t$-statistic for firm $i\left(t_{i}\right)$ is distributed Student- $t$ with variance $k_{i} /\left(k_{i}-2\right)$, the sum of standardized $t_{i} s$ is distributed normally with a variance of $N^{22}$ Under the null hypothesis that $\beta_{2}$ is zero for all firms, the Z-statistic is a standard normal variate. ${ }^{23}$

Summary statistics for the results of equation (2) for each sample are shown in Panel A of Table 3. During the fixed exchange rate period, the betas of the multinational firms (mean 1.10 and median 1.06) are lower than those of the industry control sample of domestic firms (mean 1.32 and median 1.22). This result is consistent with the findings of previous work with U.S. multinational firms suggesting that during fixed exchange rates multinational firms possessed relatively less market risk than similar domestic firms due to their geographic diversification (see, e.g., Brewer (1981) and Fatemi (1984)). With respect to the change in betas for the multinational firms, the mean $\beta_{2}$ is 0.092 , with a standard error of 0.033 , and the Z-statistic is 4.345 . Both the mean and the $\mathrm{Z}$ statistic are significant at the 1 percent level for a one-tailed test. The median change in market risk for the multinationals is 0.117 and the test-statistic from a Wilcoxon signed rank test indicates that it is also

\footnotetext{
${ }^{22}$ This follows from the Central Limit Theorem. See DeGroot (1986, pp. 393-396).

${ }^{23}$ This test is based upon the sample distribution of $\beta_{2}$. It assumes that the estimates of $\beta_{2}$ are independent across firms in the sample. To the extent this assumption does not hold, the reported test statistic will be overstated.
} 
significantly different from zero at the 1 percent level for a one-tailed test. Thus, for the test sample of multinational firms, the median (mean) beta rises significantly from $1.066(1.110)$ during the fixed exchange rate period to $1.183(1.202)$ during the floating exchange rate period.

The mean and median market risk changes for the control samples are also shown in Panel A. For the industry control sample, the mean $\beta_{2}$ is negative, -0.076 , with a standard error of 0.044 and a Z-statistic is -1.89 . Both measures suggest a statistically significant decrease in market risk for comparable domestic firms in the same activities as the multinational firms. The median $\beta_{2}$, however, while negative, is not significantly different from zero. ${ }^{24}$ For the oil control and size control samples the summary statistics for $\beta_{2}$ are close to zero and none of the tests show a significant change. This is despite the fact that the firms in these samples experienced a significant increase in volatility. Thus it seems that the increase in the systematic risk of the test sample cannot be solely ascribed to an increase in observed stock return volatility. ${ }^{25}$

As before, we replicate the tests on the four portfolios of sample firms. These results are shown in Panel B of Table 3. The results confirm the findings from the firm-by-firm results. The shift in beta for the test sample is 0.092 , which is (weakly) significant at the 7 percent level even using White (1980) corrected standard errors. The corresponding shifts in beta for the control samples are insignificantly different from zero. Though weaker than the firm-by-firm results, these portfolio results support our finding that increased exchange rate variability led to an increase in market risk for U.S. multinational firms.

\footnotetext{
${ }^{24}$ The apparent negative change in market risk for the industry control sample when considered in light of the positive change in market risk for the test sample of multinational firms suggests that the relative shift in market risk between domestic and multinational firms in similar industries was larger than the stated increase in market risk for the multinational firms alone.

${ }^{25}$ Note also that the market value of the size control firms is nearly the same as the multinationals suggesting that our results cannot simply be attributed to the fact that the multinationals make up a significant portion of the market portfolio.
} 
In summary, the results of Table 3 suggest that U.S. multinational firms show a significant increase in market risk corresponding to the increase in exchange rate variability. While all firms experienced an increase in stock price volatility following the arrival of floating exchange rates, some component of this increased volatility is systematic risk for the multinational firms compared with the other firms in the market. ${ }^{26}$

\subsection{Asset Risk}

As demonstrated by Hamada (1972), an increase in market risk can arise from either an increase in asset risk or an increase in financial leverage. Under the assumption that a firm's debt is riskless, its market risk can be written as the product of the beta of its assets (asset risk) and the ratio of the market value of the assets to the market value of the firm's equity:

$$
\beta_{l}=\beta_{i}^{a}\left(\frac{V}{E}\right)_{i}
$$

where: $\beta_{i}=$ the index of market risk of firm i from the market model;

$\beta_{i}^{a}=$ the asset risk of firm $i$

$(\mathrm{V} / \mathrm{E})_{\mathrm{i}}=$ the ratio of the market value of assets to the market value of equity for firm $i$.

From equation (4), it can be seen that increases in market risk result from increases in asset risk, $\beta_{i}{ }^{a}$, or increases in leverage, $(V / E)$. For us to suggest a link between exchange rate variability and market risk we must demonstrate that our finding of a relation between increased exchange rate variability and greater market risk for multinational firms is not just due to an increase in leverage for multinational firms. To accomplish this we examine the changes in financial leverage that occurred between the two periods.

\footnotetext{
${ }^{26}$ It should be noted that the change in market risk was not due to changes in relative market capitalization among the samples. Tests (not reported for parsimony) indicate that for all three samples the ratio of portfolio capitalization to total market capitalization in 1977 was not significantly different from the ratio of portfolio capitalization to total market capitalization in 1966.
} 
We calculate the leverage of each firm as the average ratio of firm value (market value of equity plus book value of debt) to the market value of equity, during each of the two periods. Panel A of Table 4 contains summary statistics for the cross-sectional distribution of firm leverage for each sample. These data suggest that financial leverage increased for all four samples between the two periods. Two-sample t-tests and Wilcoxon signed-rank tests indicate that for all four samples both the mean and median leverage increase significantly. Because market risk is a relative measure, an increase in leverage for all firms in the market would have no effect on the measured market risk of

any firm. Thus, to consider whether financial leverage could be responsible for the increase in market risk for the test sample of multinational firms, we compare the percentage changes in leverage for the firms in the four samples. The results of these tests, shown in Panel B of Table 4, indicate that the percentage change in leverage for the test sample $(0.329)$ is significantly smaller than the change in leverage for either the industry control $(0.617)$ or the oil control $(0.459)$ samples. Both t-tests of the mean and signed-rank tests of the median percentage change in financial leverage indicate a significantly smaller change for the multinational firms. For the size control firm, the mean and median leverage change is larger than that of the multinational firms; however, the difference is not significant. Taken together, these results suggest that the increase in beta among multinational firms following the arrival of floating exchange rates is not due to a relative increase in the financial risk of U.S. multinational firms, and therefore, as equation (4) implies, the increase in beta is due to an increase in the asset risk compared with the other firms in the U.S. market.

\subsection{Sensitivity Analysis}

In this section we consider a sensitivity test to verify that our results of an increase in market risk for U.S. multinationals corresponding to the increase in exchange rate variability are not due to omitted variables from the return generating specification. Starting with the market model, we add 
three additional factors that may also play a role as important risk factors in describing the appropriate equilibrium market portfolio: the monthly percentage change in our exchange rate index, the slope of the U.S. term structure for government bills, and the percentage change in an oil price index. These variables are added not so much to examine their factor loadings as to examine whether in a return specification process we find the same change in the index of market risk following the increase in exchange rate variability. Thus, we estimate the following expanded version of equation (2) on the four samples:

$$
\begin{aligned}
R_{i, t} & =a_{0}+\beta_{1, i} R_{m, t}+\beta_{2, i} \cdot R_{m, i} D U M_{t}+\gamma_{1, i} \cdot \Delta X R_{t}+\gamma_{2, i} \cdot \Delta X R_{i} \cdot D U M_{t} \\
& +\theta_{1, i} \cdot \mathrm{TSSL}_{\mathrm{t}}+\theta_{2, i} \cdot \mathrm{TSSL}_{\mathrm{i}} \cdot D U M_{t}+\chi_{1, i} \cdot \Delta \mathrm{Oil}_{\mathrm{t}}+\chi_{2, i} \cdot \Delta \mathrm{Oil}_{\mathrm{t}} \cdot D U M_{t}+\epsilon_{i, t}
\end{aligned}
$$

where the new variables are:

$\Delta \mathrm{XR}_{\mathrm{t}}=$ percentage change in the trade-weighted value of the U.S. dollar over month t;

$\mathrm{TSSL}_{\mathrm{t}}=$ the slope of the U.S. interest rate term structure, defined as the one year T-bill rate minus the annualized one month T-bill rate.

$\Delta \mathrm{Oil}_{\mathrm{t}}=$ the percentage change in an oil price index ${ }^{27}$

Panel A of Table 5 displays cross-sectional summary statistics from the estimation of this equation on the individual firms in each sample. ${ }^{28}$ Parameter estimates with a subscript 1 are for the first subperiod relations (1966 - 1970) and parameter estimates with a subscript 2 are for the second subperiod relations (1973 - 1977). In support of our earlier findings of a positive relation between exchange rate variability and market risk for multinational firms, there is still a significant increase in market risk for

\footnotetext{
${ }^{27}$ The description of the exchange rate index is given in a previous footnote. The interest rate data are from the bond file on the CRSP database, and the oil price data are collected from monthly supplements of the International Financial Statistics published by the international Monetary Fund.

${ }^{28}$ This test is also repeated on the four portfolios of returns. The results (not reported for space considerations) display a pattern of significance that is nearly identical to the cross-sectional results. The $\beta_{2}$ parameter is significantly positive at the 10 percent level for our test sample and insignificantly different from zero for the industry, oil, and size control portfolios.
} 
the test sample firms in the floating rate period. The mean and median $\beta_{2}$ are significantly positive at the 1 percent level. ${ }^{29}$

For the control samples, the addition of these other variables to the asset pricing model does not affect the shift in market risk during the floating rate periods. In no case is there a significant change in the level of market risk for these three samples of firms. These results thus confirm our finding that the increased market risk for multinational firms corresponding to increased exchange rate variability, and suggests that it is not due to misspecification of the return generating process.

\section{Summary and Interpretation}

This paper shows that there was a significant generalized increase in the volatility of equity returns following the onset of increased exchange rate variability. Our results, however, indicate that there are two differentiating features about this increase in stock price volatility for U.S. multinational firms compared with other U.S. firms. The first is that the increase in total stock return volatility for multinational firms is significantly larger than for three sets of control firms. Given the controls inherent in the other groups of firms, this result is consistent with a direct impact of increased exchange rate variability on the stock price volatility of multinational firms. This result adds supports the weak existing empirical evidence that exchange rates play an important role in the stock price behavior of U.S. multinational firms.

The second feature is the identification of an important difference in the economic impact of the increase in stock return volatility for the multinational firms versus the control firms. Consistent with previous evidence of a link between foreign currency risk premia and U.S. equity market risk premia over the floating rate period and our finding of exchange rate variability as an additional source of

\footnotetext{
${ }^{29}$ Note that for the multinational firms, the exchange rate variable is significantly negatively related to returns in the first (fixed rate) period, but consistent with previous research on exchange rate exposure mentioned above, the relation between the exchange rate variable and returns in the second period, $\gamma_{1}+\gamma_{2}$, is close to zero and not statistically significant.
} 
volatility for multinational firms, we find a significant increase in market risk for the multinational firms but not for the control firms. This suggests that whereas the increased stock price volatility observed for the firms in the other samples was perceived by the market as being diversifiable, exchange rate variability imparted to multinational firms (but not domestically oriented firms) additional stock price volatility that was perceived by the market as being partially systematic risk. Sensitivity tests indicate that this finding is not due to problems with omitted variables from the asset pricing specification. 


\section{References}

ADLER, M. AND B. Dumas (1984), "Exposure to Currency Risks: Definition and Measurement," Financial Management, 13, pp. 41 - 50.

ADLER, M. AND B. DUMAS (1983), "International Corporate Finance," Journal of Finance, June, pp. $1103-1161$.

AMIHUD, Y. (1993) " Exchange Rates and the Valuation of Equity Shares," in Y. Amihud and R. Levich (eds.) Exchange Rates and Corporate Performance, (Business One, Irwin: Homewood IL) forthcoming.

BARTOV, E. AND G. M. BODNAR (1994), "Firm Valuation, Earnings Expectations and the Exchange Rate Exposure Effect," Journal of Finance, 49 (5), pp. 1755 - 86.

BODNAR, G. M., AND W. M. GENTRY (1993), "Exchange Rate Exposure and Industry Characteristics: Evidence from Canada, Japan and the U.S.," Journal of International Money and Finance, 12 , pp. $29-45$.

BREWER, H., L. (1981), "Investor Benefits from Corporate International Diversification," Journal of Financial and Quantitative Analysis, March, pp. 113-26.

CHIANG, T., C. (1991), "International Assets Pricing and Equity Market Risk," Journal of International Money and Finance, 10 pp. 349 - 64.

Chen, N., R. Roll, and S. A. Ross (1986), "Economic Forces and the Stock Market," Journal of Business, 59 pp. 383 - 403.

DeGroot, M. (1986) Probability and Statistics, Second Edition, (Reading, MA: Addisson Wesley).

DIRECTORY OF AMERICAN FIRMS OPERATING IN FOREIGN COUNTRIES, (1966) 6th Edition, (New York: World Trade Academy Press Inc.).

DumAs, B. (1978), "The Theory of the Trading Firm Revisited," Journal of Finance, June, pp. $1019-29$.

FATEMI, A. (1984) "Shareholder Benefits from Corporate Diversification," Journal of Finance, December, pp. 1325 - 44.

HAMADA, R. (1972), "The Effect of the Firm's Capital Structure on the Systematic Risk of Common Stocks," Journal of Finance, 27, pp.435 - 452.

JACQUILLAT, B. AND B, SOLNIK (1978), "Multinationals are Poor Tools for International Diversification," Journal of Portfolio Management, Winter, pp. 8 - 12.

JORION, P. (1990), "The Exchange Rate Exposure of U.S. Multinational Firms," Journal of Business, July, pp. 331 - 45. 
JORION, P. (1991), "The Pricing of Exchange Rate Risk in the U.S. Equity Markets," Journal of Financial and Quantitative Analysis, July, pp. 363 - 76.

KorajCzyK, R. A., And C. J. Viallet (1992), "Equity Risk Premia and the Pricing of Foreign Exchange Risk ," Journal of International Economics, 33, pp. 199 - 219.

LEVI, M. D. (1990), International Finance, Second Edition (McGraw Hill: New York).

MCCURDY, T. H., AND I. MORGAN, (1991), "Tests for a Systematic component in Deviations from Uncovered Interest Parity," Review of Economic Studies, 58, pp. 587 - 602.

RoBICHeK, A., A., AND M. R. EAKER (1978) "Foreign Exchange Hedging and the Capital Asset Pricing Model," Journal of Finance, 33(3), pp. 1011 - 18.

SHAPIRO, A. C. (1974), "Exchange Rate Changes, Inflation and the Value of the Multinational Corporation," Journal of Finance, 30, pp. 485- 502.

Shapiro, A. C. And S. TitMan (1985), "Why Total Risk Matters," Midland Corporate Finance Journal, Summer, pp. 243-65.

SMITH, C., W., C. SMITHSON, AND S. WILFORD (1990) Managing Financial Risk, (Harper \& Row: New York).

SOLNIK, B, (1991) International Investments, Second Edition, (Reading, MA: Addison Wesley).

THEIL, H. (1971) Principles of Econometrics, (John Wiley and Sons: New York).

The Wall Street JouRnal, (1991) "The Dollar Rally: Hit in Profits May Drag Down Stock Market....," July 8, p. C1.

WhITE, H. (1980) "A Heteroskedasticity-Consistent Covariance matrix Estimator and a Direct Test for Heteroskedasticity," Econometrica, 48, pp. 817 - 38. 
Table 1

Descriptive Statistics

\begin{tabular}{|c|c|c|c|c|c|c|c|c|c|c|c|c|}
\hline \multirow[b]{2}{*}{ Statistic } & \multicolumn{3}{|c|}{ Test Sample } & \multicolumn{2}{|c|}{$\begin{array}{c}\text { Industry } \\
\text { Control Sample }\end{array}$} & \multirow[b]{2}{*}{$\underline{\mathrm{Q}}$} & \multicolumn{3}{|c|}{$\begin{array}{c}\text { Oil } \\
\text { Control Sample }\end{array}$} & \multicolumn{3}{|c|}{$\begin{array}{c}\text { Size } \\
\text { Control Sample }\end{array}$} \\
\hline & Q1 & Median & $\underline{\mathrm{Q} 3}$ & $\underline{\mathrm{Q} 1}$ & $\underline{\text { Median }}$ & & $\underline{Q 1}$ & $\underline{\text { Median }}$ & $\underline{\mathrm{Q} 3}$ & $\underline{\mathrm{Q}}$ & Median & $\underline{\mathrm{Q} 3}$ \\
\hline \multicolumn{13}{|l|}{ 1. Market value of Common } \\
\hline Equity (\$ million) & 347.5 & 729.5 & 1888.1 & 44.4 & 161.7 & 454.4 & 366.2 & 598.9 & 1044.5 & 418.5 & 682.1 & 1393.9 \\
\hline 2. Annual sales ( $\$$ million) & 345.8 & 844.4 & 1587.1 & 84.3 & 247.4 & 607.5 & 238.2 & 567.1 & 1379.6 & 423.3 & 816.3 & 1636.3 \\
\hline 3. Total assets ( $\$$ million) & 337.5 & 634.4 & 1514.0 & 76.6 & 208.5 & 533.9 & 703.8 & 1245.5 & 2308.5 & 462.6 & 989.9 & 1708.8 \\
\hline 4. Debt-equity ratio & 0.129 & 0.335 & 0.687 & 0.252 & 0.461 & 1.018 & 0.684 & 1.233 & 1.564 & 0.187 & 0.597 & 0.999 \\
\hline 5. Earnings per Share/Price & 0.026 & 0.047 & 0.068 & 0.048 & 0.068 & 0.093 & 0.068 & 0.087 & 0.095 & 0.040 & 0.063 & 0.083 \\
\hline
\end{tabular}

Tables Notes: The comparisons are for fiscal year 1972 (arbitrarily chosen). The number of firms used for computing the statistics is determined by data availability and is 109 for the test sample and ranges between 108 to 109 for industry control sample and between 106 to 109 for the oil control and size control sample. 
Table 2

Stock Return Variability Across Exchange-Rate Regimes

Panel A : Cross-Sectional Distribution of Stock Return Variances

\section{Fixed Exchange \\ Rates}

Test Sample

$\begin{array}{cc}\text { Mean } & 0.0077 \\ \text { Median } & 0.0061 \\ \text { Q1 } & 0.0045 \\ \text { Q3 } & 0.0095\end{array}$

Industry Control Sample

$\begin{array}{cl}\text { Mean } & 0.0125 \\ \text { Median } & 0.0089 \\ \text { Q1 } & 0.0063 \\ \text { Q3 } & 0.0156\end{array}$

Oil Control Sample

$\begin{array}{ccccc}\text { Mean } & 0.0055 & 0.0069 & 623.7 & 0.000 \\ \text { Median } & 0.0043 & 0.0058 & 3.379 & 0.001 \\ \text { Q1 } & 0.0031 & 0.0041 & & \\ \text { Q3 } & 0.0074 & 0.0085 & & \end{array}$

$\underline{\text { Size Control Sample }}$

$\begin{array}{ccccc}\text { Mean } & 0.0074 & 0.0097 & 643.7 & 0.000 \\ \text { Median } & 0.0063 & 0.0082 & 3.919 & 0.001 \\ \text { Q1 } & 0.0049 & 0.0066 & & \\ \text { Q3 } & 0.0087 & 0.0120 & & \end{array}$

$\begin{array}{lll}0.0149 & 543.0 & 0.000 \\ 0.0111 & 2.027 & 0.021 \\ 0.0075 & & \\ 0.0182 & & \end{array}$

$\begin{array}{ccc}\begin{array}{c}\text { Floating Exchange } \\ \text { Rates } \\ (1973-1977)\end{array} & \begin{array}{c}\text { Test } \\ \text { Statistic }\end{array} & \\ & & \\ & \text { Significanc } \\ 0.0107 & 706.0 & 0.000 \\ 0.0094 & 3.108 & 0.001 \\ 0.0067 & & \\ 0.0128 & & \end{array}$

$\begin{array}{ccc}\begin{array}{c}\text { Floating Exchange } \\ \text { Rates } \\ (1973-1977)\end{array} & \begin{array}{c}\text { Test } \\ \text { Statistic }\end{array} & \\ & & \\ & \text { Significanc } \\ 0.0107 & 706.0 & 0.000 \\ 0.0094 & 3.108 & 0.001 \\ 0.0067 & & \\ 0.0128 & & \end{array}$

0.0128

Rates Test

(1973-1977) $\quad \underline{\text { Statistic } \quad \underline{\text { Significance }}}$

0.0182
0.0069
0.0041
0.0085

.000

0.021

0.000

001

\section{Panel B : Cross-Sectional Distributions of Relative Stock Return Variances}

(variance in floating rate period / variance in fixed rate period)

\begin{tabular}{lccccc} 
Mest Sample & $\begin{array}{c}\text { Industry } \\
\text { Control Sample }\end{array}$ & $\begin{array}{c}\text { Oil } \\
\text { Control Sample }\end{array}$ & $\begin{array}{c}\text { Size } \\
\text { Control Sample }\end{array}$ \\
\cline { 2 - 3 } Median & 1.53 & 1.35 & & 1.45 & 1.44 \\
Q1 & 1.41 & 1.26 & & 1.31 & 1.31 \\
Q3 & 1.13 & 0.91 & & 0.95 & 0.91 \\
& 1.83 & 1.69 & 1.66 & 1.80 \\
arison of the Distribution to the Test Sample & & & \\
\multicolumn{2}{l}{ Wilcoxon Rank-Sum Statistic } & 2.283 & & 1.804 & 1.782 \\
\multicolumn{2}{l}{ Significance } & 0.011 & 0.036 & 0.038
\end{tabular}


Table 2 (con't)

Stock Return Variability Across Exchange-Rate Regimes

\begin{tabular}{|c|c|c|c|c|}
\hline \multicolumn{5}{|c|}{ Panel C: Portfolio Stock Return Variance } \\
\hline Portfolio & $\begin{array}{c}\begin{array}{c}\text { Fixed Exchange } \\
\text { Rates }\end{array} \\
(1966-1970) \\
\end{array}$ & $\begin{array}{c}\text { Floating Exchange } \\
\text { Rates } \\
(1973-1977) \\
\end{array}$ & $\begin{array}{c}\text { Test } \\
\text { Statistic }\end{array}$ & $\underline{\text { Significance }}$ \\
\hline Test Sample & 0.0026 & 0.0041 & 1.592 & 0.038 \\
\hline Industry Control Sample & 0.0040 & 0.0052 & 1.345 & 0.132 \\
\hline Oil Control Sample & 0.0020 & 0.0027 & 1.373 & 0.115 \\
\hline Size Control Sample & 0.0025 & 0.0034 & 1.401 & 0.102 \\
\hline
\end{tabular}

Table Notes: Panel A - The numbers are summary statistics for the variance of the firm's stock returns expressed as percent squared in decimal form. The test statistic for the mean is a test that all of the individual changes in variance for the sample are jointly significant and is distributed chi-squared with 218 degrees of freedom. The test statistic for the median is from a Wilcoxon signed-rank (median) test. Both reported significance levels are for the one-tailed test that the variance has increased between periods. Panel B - Summary statistics are for the ratio of variance in 1973-1977 to variance in 1966-1970 for each sample. The test statistic is from a Wilcoxon rank-sum test for the difference in the distributions of the relative variances and the reported significance level is for the onetailed test that the distribution of the test sample is higher than for the other sample. Panel C - The reported numbers are return variances to equally weighted portfolios of each sample, expressed as percentage squared, in decimal form. The F-statistic is the ratio of the variance of $1973-1977$ to the variance in $1966-1970$, and the reported significance is for the one tailed test that the variance increases between the two periods. Note all variances expressed as percent squared in decimal form. 
Table 3

Change in Systematic Risk Across Exchange Rate Regimes

Panel A: Cross-Sectional Distribution of Changes in Market Risk

$$
R_{i, t}=a_{0}+\beta_{1, i} \cdot R_{m, t}+\beta_{2, i} R_{m, i} D U M_{t}+\epsilon_{i, t}
$$

\begin{tabular}{|c|c|c|c|c|c|c|}
\hline & Mean & $\begin{array}{c}\underline{\beta}_{1} \\
\text { Z-Statistic }\end{array}$ & $\underline{\text { Median }}$ & $\underline{\text { Mean }}$ & $\begin{array}{c}\underline{\beta}_{2} \\
\text { Z-Statistic }\end{array}$ & $\underline{\text { Median }}$ \\
\hline Test Sample & $\begin{array}{c}1.110 \\
(0.033)\end{array}$ & 54.66 & $\begin{array}{c}1.066 \\
{[0.00]}\end{array}$ & $\begin{array}{c}0.092 \\
(0.033)\end{array}$ & 4.35 & $\begin{array}{c}0.117 \\
{[0.00]}\end{array}$ \\
\hline Industry Control Sample & $\begin{array}{c}1.321 \\
(0.045)\end{array}$ & 52.48 & $\begin{array}{c}1.220 \\
{[0.00]}\end{array}$ & $\begin{array}{c}-0.076 \\
(0.044)\end{array}$ & -1.89 & $\begin{array}{c}-0.036 \\
{[0.91]}\end{array}$ \\
\hline Oil Control Sample & $\begin{array}{c}0.895 \\
(0.032)\end{array}$ & 49.32 & $\begin{array}{l}0.827 \\
{[0.00]}\end{array}$ & $\begin{array}{c}-0.011 \\
(0.029)\end{array}$ & -0.17 & $\begin{array}{l}0.016 \\
{[0.48]}\end{array}$ \\
\hline Size Control Sample & $\begin{array}{c}1.112 \\
(0.035)\end{array}$ & 31.77 & $\begin{array}{c}1.062 \\
{[0.00]}\end{array}$ & $\begin{array}{c}-0.015 \\
(0.037)\end{array}$ & -0.69 & $\begin{array}{c}0.018 \\
{[0.57]}\end{array}$ \\
\hline
\end{tabular}

Panel B: Portfolio Tests of Changes in Market Risk

$$
R_{i, l}=a_{0}+\beta_{1, i} R_{m, t}+\beta_{2, i} \cdot R_{m, i} D U M_{1}+\epsilon_{i, l}
$$

\begin{tabular}{|c|c|c|c|c|}
\hline Test Sample & $\begin{array}{c}\beta_{1} \\
1.110 \\
(0.045)\end{array}$ & $\begin{array}{c}\beta_{2} \\
0.092 \\
(0.063)\end{array}$ & $\begin{array}{l}\text { t-Statistic } \\
\text { for } \beta_{2} \\
1.470\end{array}$ & $\begin{array}{c}\text { Significance } \\
\frac{\left(\mathrm{H}_{0}, \beta_{2}>0\right)}{0.071}\end{array}$ \\
\hline Industry Control Sample & $\begin{array}{c}1.321 \\
(0.085)\end{array}$ & $\begin{array}{l}-0.076 \\
(0.177)\end{array}$ & -0.429 & 0.666 \\
\hline Oil Control Sample & $\begin{array}{c}0.896 \\
(0.066)\end{array}$ & $\begin{array}{l}-0.012 \\
(0.111)\end{array}$ & -0.108 & 0.554 \\
\hline Size Control Sample & $\begin{array}{c}1.112 \\
(0.022)\end{array}$ & $\begin{array}{l}-0.015 \\
(0.058)\end{array}$ & -0.258 & 0.603 \\
\hline
\end{tabular}

Table Notes: Panel A - $\beta_{1}$ and $\beta_{2}$ are the mean OLS estimates of the market exposure for individual firms in each of the three samples (standard error of the mean in parentheses). The test statistic is a unit normal Z-statistic for the joint significance of the $\beta_{2}$ estimates for each sample. The p-values for the median $\beta_{2}$ is a from a Wilcoxon signed rank test. Reported significance levels for both tests are for one-tailed tests. ${ }^{*}$ and ${ }^{* *}$ represent significance at the 1 and 5 percent levels, respectively. Panel B - The numbers are OLS estimates of the market exposure for each of the three equally weighted portfolios of firms. The standard errors in parentheses are White (1980) corrected standard errors and the reported significance for the White based $t$-statistics is for a one-tailed test. 
Table 4

Financial Leverage Across Exchange Rate Regimes

\begin{tabular}{|c|c|c|c|c|}
\hline \multicolumn{5}{|c|}{ Panel A: Cross-Sectional Distribution of Financial Leverage } \\
\hline & & & Test & Significance \\
\hline & $\underline{1966-1970}$ & $\underline{1973-1977}$ & Statistic & p-value \\
\hline \multicolumn{5}{|l|}{ Test Sample } \\
\hline Mean & 1.503 & 2.019 & 4.955 & 0.000 \\
\hline Median & 1.364 & 1.628 & 3.530 & 0.000 \\
\hline \multicolumn{5}{|c|}{ Industry Control Sample } \\
\hline Mean & 1.880 & 3.121 & 3.282 & 0.001 \\
\hline Median & 1.506 & 2.070 & 5.431 & 0.000 \\
\hline \multicolumn{5}{|c|}{ Oil Control Sample } \\
\hline Mean & 1.974 & 2.862 & 9.731 & 0.000 \\
\hline Median & 1.959 & 2.920 & 7.603 & 0.000 \\
\hline \multicolumn{5}{|c|}{ Size Control Sample } \\
\hline Mean & 1.669 & 2.357 & 3.963 & 0.001 \\
\hline Median & 1.473 & 1.921 & 3.930 & 0.001 \\
\hline
\end{tabular}

Panel B: Comparison of Percentage Changes in Leverage Across Samples

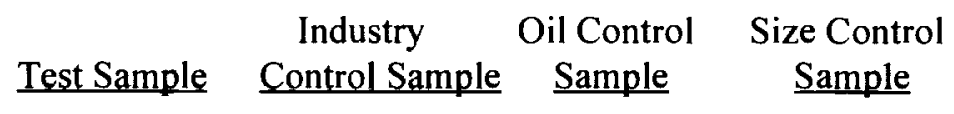

Mean $\% \Delta$ in Leverage

0.329

0.617

0.459

0.378

Comparison to Test Sample:

t-Statistic

0.773

Significance

0.007

0.007

0.220

Median $\% \Delta$ in Leverage

0.192

0.323

0.430

0.237

Comparison to Test Sample:

$\begin{array}{lll}2.265 & 4.695 & 1.002 \\ 0.012 & 0.000 & 0.158\end{array}$

Test-Statistic

0.000

0.158

Table Notes: Panel A - the summary statistics are for the cross sectional distribution of financial leverage, defined as book value of debt to market value of equity, for each of the firms in the three samples. The test statistic for the means is from a two-sample $t$-test, and the test statistic for the median is from a Wilcoxon signed-rank (median) test. Reported significance levels for each test are for one-tailed tests. Panel B - the summary statistics are for the percentage change in leverage for each firms in the samples. The tests compare the mean and median percentage change in leverage for the test sample against the control sample and the oil sample. For the mean the test statistic is from a two sample t-test, and for the median the test statistic is from a Wilcoxon signed-rank (median) test. The reported significance levels are for one-tailed tests. 
Table 5

Sensitivity Tests for Changes in Market Beta Across Exchange Rate Regimes

$$
R_{t}=a_{0}+\beta_{1} \cdot R_{m, t}+\beta_{2} \cdot R_{m, t} D U M_{t}+\gamma_{1} \cdot \Delta X R_{t}+\gamma_{2} \cdot \Delta X R_{i} D U M_{t}+\theta_{1} \cdot \mathrm{TSSL}_{t}+\theta_{2} \cdot \mathrm{TSSL} L_{t} D U M_{t}+\chi_{1} \cdot \Delta \mathrm{Oil}_{\mathrm{t}}+\chi_{2} \cdot \Delta \mathrm{Oil}_{\mathrm{t}} \cdot D U M_{t}+\epsilon_{t}
$$

\begin{tabular}{|c|c|c|c|c|c|c|c|c|}
\hline \multicolumn{9}{|c|}{ Panel A: Cross Sectional Results } \\
\hline & \multicolumn{2}{|c|}{ Market Factor } & \multicolumn{2}{|c|}{ Exchange Rate Factor } & \multicolumn{2}{|c|}{ Term Structure Factor } & \multicolumn{2}{|c|}{ Oil Price Factor } \\
\hline & $\underline{\boldsymbol{\beta}}_{1}$ & $\underline{\boldsymbol{\beta}}_{2}$ & $\underline{x}_{1}$ & $\underline{x}_{2}$ & $\underline{\theta}_{1}$ & $\underline{\theta}_{2}$ & $x_{1}$ & $x_{2}$ \\
\hline \multicolumn{9}{|l|}{ Test Sample } \\
\hline Mean & $1.100^{\mathrm{a}}$ & $0.110^{\mathrm{a}}$ & $-0.628^{\mathrm{a}}$ & $0.664^{a}$ & $-0.0053^{\mathrm{a}}$ & 0.0003 & $-0.109^{b}$ & $0.130^{\mathrm{a}}$ \\
\hline Stnd Error & $(0.032)$ & $(0.031)$ & $(0.228)$ & $(0.222)$ & $(0.0017)$ & $(0.0017)$ & $(0.056)$ & $(0.058)$ \\
\hline Z-Stat & 51.86 & 4.75 & -2.84 & 2.75 & -2.88 & -0.32 & 0.93 & 1.13 \\
\hline Median & 1.073 & 0.153 & -0.573 & 0.464 & -0.0066 & 0.0031 & -0.136 & -0.155 \\
\hline p-value & {$[0.00]$} & {$[0.00]$} & {$[0.01]$} & {$[0.00]$} & {$[0.00]$} & [0.69] & {$[0.42]$} & {$[0.02]$} \\
\hline \multicolumn{9}{|c|}{ Control Sample } \\
\hline Mean & $1.321^{\mathrm{a}}$ & -0.069 & -0.037 & 0.127 & -0.0025 & $0.0045^{\mathrm{a}}$ & $-0.135^{b}$ & $0.195^{\mathrm{a}}$ \\
\hline Stnd Error & $(0.045)$ & $(0.045)$ & $(0.314)$ & $(0.314)$ & $(0.0024)$ & $(0.0018)$ & $(0.087)$ & $(0.088)$ \\
\hline Z-Stat & 51.28 & -1.76 & 0.62 & 0.72 & -1.11 & 2.56 & -1.10 & 1.58 \\
\hline Median & 1.208 & -0.036 & -0.499 & 0.644 & -0.0052 & 0.0049 & -0.210 & 0.270 \\
\hline p-value & {$[0.00]$} & {$[0.19]$} & {$[0.73]$} & {$[0.47]$} & {$[0.28]$} & {$[0.00]$} & {$[0.03]$} & {$[0.01]$} \\
\hline \multicolumn{9}{|l|}{ Oil Sample } \\
\hline Mean & $0.897^{\mathrm{a}}$ & -0.014 & -0.077 & 0.168 & -0.0015 & $0.0069^{\mathrm{a}}$ & 0.053 & -0.042 \\
\hline Stnd Error & $(0.032)$ & $(0.029)$ & $(0.296)$ & $(0.298)$ & $(0.0013)$ & $(0.0011)$ & $(0.076)$ & $(0.075)$ \\
\hline Z-Stat & 48.95 & 0.08 & -1.02 & 1.31 & -1.43 & 5.90 & 0.86 & -0.70 \\
\hline Median & 0.827 & 0.023 & -0.710 & 0.642 & -0.0035 & 0.0075 & -0.009 & 0.006 \\
\hline p-value & {$[0.00]$} & {$[0.95]$} & {$[0.13]$} & {$[0.08]$} & {$[0.08]$} & {$[0.00]$} & {$[0.75]$} & {$[0.89]$} \\
\hline \multicolumn{9}{|l|}{ Size Sample } \\
\hline Mean & $1.113^{\mathrm{a}}$ & -0.004 & -0.269 & 0.374 & 0.0001 & -0.0033 & 0.037 & -0.029 \\
\hline Stnd Error & $(0.035)$ & $(0.037)$ & $(0.300)$ & $(0.299)$ & $(0.0024)$ & $(0.0031)$ & $(0.078)$ & $(0.079)$ \\
\hline Z-Stat & 31.80 & -0.11 & -0.89 & 1.25 & 0.04 & 1.06 & 0.47 & -0.36 \\
\hline Median & 1.054 & 0.047 & -0.455 & 0.308 & -0.0023 & -0.0035 & -0.048 & 0.012 \\
\hline$p$-value & {$[0.00]$} & {$[0.25]$} & {$[0.70]$} & {$[0.25]$} & {$[0.85]$} & {$[0.57]$} & {$[0.57]$} & {$[0.70]$} \\
\hline
\end{tabular}


Table Notes: The variables are defined as follows: $R_{i, t}$ is the return to firm $i$ in month $t, R_{m, t}$ is the return to the value-weighted CRSP market index for month $t, \Delta X R_{1}$ is the percentage change in the trade-weighted index of the U.S. dollar over period t, TSSL $t_{t}$ is the slope of the U.S. Treasury bill term structure, $\Delta \mathrm{Oil}_{\mathrm{t}}$ is the percentage change in an oil price index and DUM, is a dummy variable that takes a value of one for the period $1973-1977$ and zero otherwise. Parameters with a subscript 2 are the shift parameter for the relation between that variable and portfolio returns in the second period. Data are monthly over the period $1966-1970$ and $1973-1977$. The first number is the mean of the cross-section of parameter estimates. The number below it in parentheses is the standard error of the mean. Superscript a and $b$ denote statistical significance at the 1 and 5 percent levels respectively for one-tailed tests. The third number is the Z-statistic: a unit normal summary statistic for the significant of the parameter estimate based upon the $t$ statistics of the entire distribution. The number in the row labeled median is the median of the cross section of parameter estimates and the number below in square brackets is the $\mathrm{p}$-value of the sign-rank test that the median is significantly different from zero. 